\title{
Utilization profile of the Canadian-led coalition Role 2 Medical Treatment Facility in Iraq: the growing requirement for multinational interoperability
}

\author{
LCol Mark P. DaCambra, MD \\ Capt (Navy) Raymond L. Kao, MD \\ LCol Christopher Berger, MD \\ LCol Vivian C. McAlister, MB
}

Accepted Oct. 9, 2018

\author{
Correspondence to: \\ M.P. DaCambra \\ Sunnybrook Health Sciences Centre \\ MG-317, 2075 Bayview Ave \\ Toronto ON M4N 3M5 \\ mark.dacambra@sunnybrook.ca
}

DOI: $10.1503 . c j s .015218$
Background: The Canadian Armed Forces deployed a Role 2 Medical Treatment Facility (R2MTF) to Iraq in November 2016 as part of Operation IMPACT. We compared the multinational interoperability required of this R2MTF with that of similar facilities previously deployed by Canada or other nations.

Methods: We reviewed data (Nov. 4, 2016, to Oct. 3, 2017) from the electronic Disease and Injury Surveillance Report and the Daily Medical Situation Report. Clinical activity was stratified by Global Burden of Diseases category, ICD-10 code, mechanism of injury, services used, encounter type, nationality and blood product usage. We reviewed the literature to identify utilization profiles for other MTFs over the last 20 years.

Results: In total, 1487 patients were assessed. Of these, $5.0 \%$ had battle injuries requiring damage-control resuscitation and/or damage-control surgery, with 55 casualties requiring medical evacuation after stabilization. Trauma and disease non-battle injuries accounted for $44 \%$ and $51 \%$ of patient encounters, respectively. Other than dental conditions, musculoskeletal disorders accounted for most presentations. Fiftyseven units of fresh frozen plasma and 64 units of packed red blood cells were used, and the walking blood bank was activated 7 times. Mass casualty activations involved coordination of health care and logistical resources from more than 12 countries. In addition to host nation military and civilian casualties, patients from 15 different countries were treated with similar frequency.

Conclusion: The experience of the Canadian R2MTF in Iraq demonstrates the importance of multinational interoperability in providing cohesive medical care in coalition surgical facilities. Multinational interoperability derives from a unique relationship between higher medical command collaboration, international training and adherence to common standards for equipment and clinical practice.

Contexte : Les Forces armées canadiennes ont déployé une installation de traitement médical de rôle 2 (ITMR2) en Iraq en novembre 2016 dans le cadre de l'opération IMPACT. Nous avons comparé l'interopérabilité multinationale requise par cette ITMR2 à celle d'installations semblables déjà déployées par le Canada ou d'autres pays.

Méthodes : Nous avons examiné les données (du 4 novembre 2016 au 3 octobre 2017) du rapport électronique de surveillance des maladies et des blessures et du rapport quotidien sur la situation médicale. L'activité clinique a été stratifiée selon la catégorie du fardeau mondial des maladies, le code de la CIM-10, le mécanisme de traumatisme, les services utilisés, le type de contact, la nationalité et l'utilisation de produits sanguins. Enfin, nous avons aussi examiné la littérature pour déterminer les profils d'utilisation d'autres ITM au cours des 20 dernières années.

Résultats : Au total, 1487 patients ont été évalués. De ce nombre, 5,0 \% avaient subi des blessures au combat qui nécessitaient une réanimation ou une intervention chirurgicale de contrôle des dommages, ou les deux, et 55 blessés avaient eu besoin d'évacuation médicale après stabilisation. Les traumatismes et les maladies non liées au combat représentaient respectivement $44 \%$ et $51 \%$ des contacts avec les patients. Outre les troubles dentaires, les troubles musculosquelettiques étaient à l'origine de la plupart des présentations. Par ailleurs, 57 unités de plasma frais congelé et 64 unités de concentré de globules rouges ont été utilisées, et la banque de sang ambulante a été activée 7 fois. La mobilisation nécessaire pour traiter un nombre massif de victimes a nécessité la coordination des soins de santé et des ressources logistiques de plus de 
12 pays. En plus des victimes militaires et civiles du pays hôte, des patients de 15 pays différents ont été traités à une fréquence semblable.

Conclusion : L'expérience de l'ITMR2 canadienne en Iraq démontre l'importance de l'interopérabilité multinationale quant à la prestation de soins médicaux cohérents dans les installations chirurgicales de la coalition. L'interopérabilité multinationale découle d'une relation unique s'appuyant sur la collaboration des membres du commandement médical supérieur, de la formation internationale et le respect de normes communes pour l'équipement et la médecine clinique.

n October 2016, Canada deployed 45 medical personnel to Erbil, Iraq, at the request of the host nation to establish a Role 2 Medical Treatment Facility (R2MTF). This medical capability was in support of the United States (US)-led Global Coalition effort to advise and assist local Peshmerga and Iraqi Forces in the defeat of Daesh. ${ }^{1}$ This was the first time in 20 years that Canada deployed an R2MTF in a hostile environment.

Operation IMPACT is the Canadian Armed Forces' (CAF) support to the Global Coalition against Daesh in Iraq and Syria. ${ }^{1}$ Daesh advocates radical interpretations of Islam, claiming religious authority over all Muslims. It aims to create a caliphate in the Levant, a region that includes modern Iraq, Syria, Lebanon, Israel, Jordan, Cyprus and Turkey. Canada joined the coalition in the summer of 2014 to dismantle and ultimately defeat Daesh. The coalition includes many of Canada's traditional allies and important regional partners. The primary mandate of the R2MTF was to provide life-saving medical and surgical care to coalition forces. Norway, Germany and the United States provided personnel to augment the Canadian contingent. The United States operated a primary care medical facility that was colocated with the Canadianled R2MTF. Seven other primary care facilities, known as Role 1 (R1) MTFs, were operated elsewhere in the camp by Canada, Britain, France, Germany, the Netherlands, Hungary and Italy. Forward damage-control surgery (DCS) teams from the United States, Belgium, the Netherlands and Canada were based on the camp, while Sweden operated a mobile forward damage-control resuscitation (DCR) team. The R2MTF lay within an evacuation system operated by the United States, with a US-led Role 3 (R3) MTF in Baghdad and a US-led Role 4 (R4) MTF in Landstuhl, Germany, being the points of evacuation for the R2MTF. All points along the evacuation chain were supported by the Joint Trauma System (JTS), which included clinical practice guidelines (CPGs) and a weekly patientbased clinical teleconference. ${ }^{2}$

Echelons of care are described by the North Atlantic Treaty Organization (NATO) from primary care (R1) to comprehensive care (R4). ${ }^{3}$ An R2MTF is capable of receiving and triaging a small number of severe casualties by performing DCR and DCS, unlike an R1MTF, which has DCR capability only. An R2MTF has limited laboratory and diagnostic imaging capabilities as well as a small patient holding capacity. A recent experience of a single- nation R2MTF, operated by France in the Central African Republic, showed that the types of cases seen changed over time and demonstrated the importance of a continuous training program during periods of low surgical activity. ${ }^{4}$

Combat engagements in recent years have become increasingly multinational, with a coalition response to insurgent activities. ${ }^{4-10}$ The R3MTF at Kandahar Airfield in Afghanistan from 2006 to 2011 demonstrated that medical specialists are often in short supply and a multilateral effort is required to staff a standing field hospital for any prolonged period of time. ${ }^{7}$ Usually, R1MTF and R2MTF assets are small enough to be staffed by and used to support solely the supplying nation. The R2MTF in Erbil, however, was staffed and used by multiple nations. This reflects a trend, which is evident in a review of the medical literature, toward an international collaborative solution for deployed medical care $\mathrm{e}^{11-15}$ (Table 1).

The objective of this study was to analyze the casualty burden and utilization profile seen at the R2MTF in this theatre of operations in order to analyze the importance of multinational interoperability in a coalition surgical facility.

\section{Methods}

Data were prospectively collected using electronic databases from the Canadian-led R2MTF in Erbil, Iraq, over a 12-month period from November 2016 to October 2017. Information was abstracted from the Disease and Injury Surveillance Report and the Daily Medical Situation Report (DM-SITREP) and retrospectively reviewed. Clinical activity was quantified by type of injury, services used, referral source, patient nationality, and diagnostic imaging/ laboratory use. Type of injury was categorized as battle injuries (BI), trauma non-battle injuries (TNBI) or disease non-battle injuries (DNBI). ${ }^{16}$ Battle injury was defined as any injury incurred as the direct result of hostile action sustained in combat or while going to or from a combat mission; TNBIs included any traumatic injury that was not a direct result of combat, including self-inflicted wounds; and DNBIs included conditions resulting from a medical illness or complications of trauma occurring more than 7 days after the index event. In addition, information on the amount and type of blood products used and walking blood bank activation was collected and tabulated. Specific diagnoses were made based on ICD-10 and Global Burden of Disease (GBD) categories. 
The study was approved by the R2MTF commanding officer and was granted a waiver by the Research Ethics Board of Western University (REB \#109631).

\section{Results}

Over the first 12 months that Canada led the R2MTF in Erbil, a total of 1487 patients were assessed. Of the non-dental patient encounters, 489 (60\%) were emergency medicine, 214 (26\%) were orthopedic surgery and 67 (8\%) were general surgery consultations. Surgical intervention was required in 50 cases (Fig. 1). The rates of BIs, TNBIs and DNBIs were relatively stable throughout the study period, but spikes in activity in all 3 areas were observed in December 2016; spikes in DNBIs and TNBIs were seen in June and July 2017, respectively (Fig. 2). There were 14 cases of DCR/DCS, 20 cases of primarily orthopedic surgery and 16 cases of general surgery/trauma. The rate of admissions into the R2MTF fluctuated significantly throughout the year, although the average length of stay per patient was relatively constant (Fig. 3). The specific services used also fluctuated over time, with the highest rates of emergency medicine and orthopedic consultations occurring in December-January, with another peak in May-June. The rate of general surgery consultations remained relatively constant throughout the study period (Fig. 4). In total, $47 \%$ of all consultations at the R2MTF were for US military personnel, $15 \%$ were for Canadians, $10 \%$ were for Italians and the rest were evenly distributed among the other 12 countries (Fig. 5). Of the 685 dental emergencies treated, $40 \%$ were for US service members, $14 \%$ were for Italians, $12 \%$ were for Canadians and the rest were evenly distributed among the remaining countries (Fig. 6). Numerous host nation personnel were treated at the R2MTF as well. Although most were contractors $(77 \%)$, a significant number of host nation forces (15\%), civilian $(5 \%)$ and detainee $(4 \%)$ populations were assessed and treated as well (Fig. 7). Of the detainees and host nation forces treated, $100 \%(n=3)$ and $79 \%(n=11)$, respectively, were for BIs. Although there

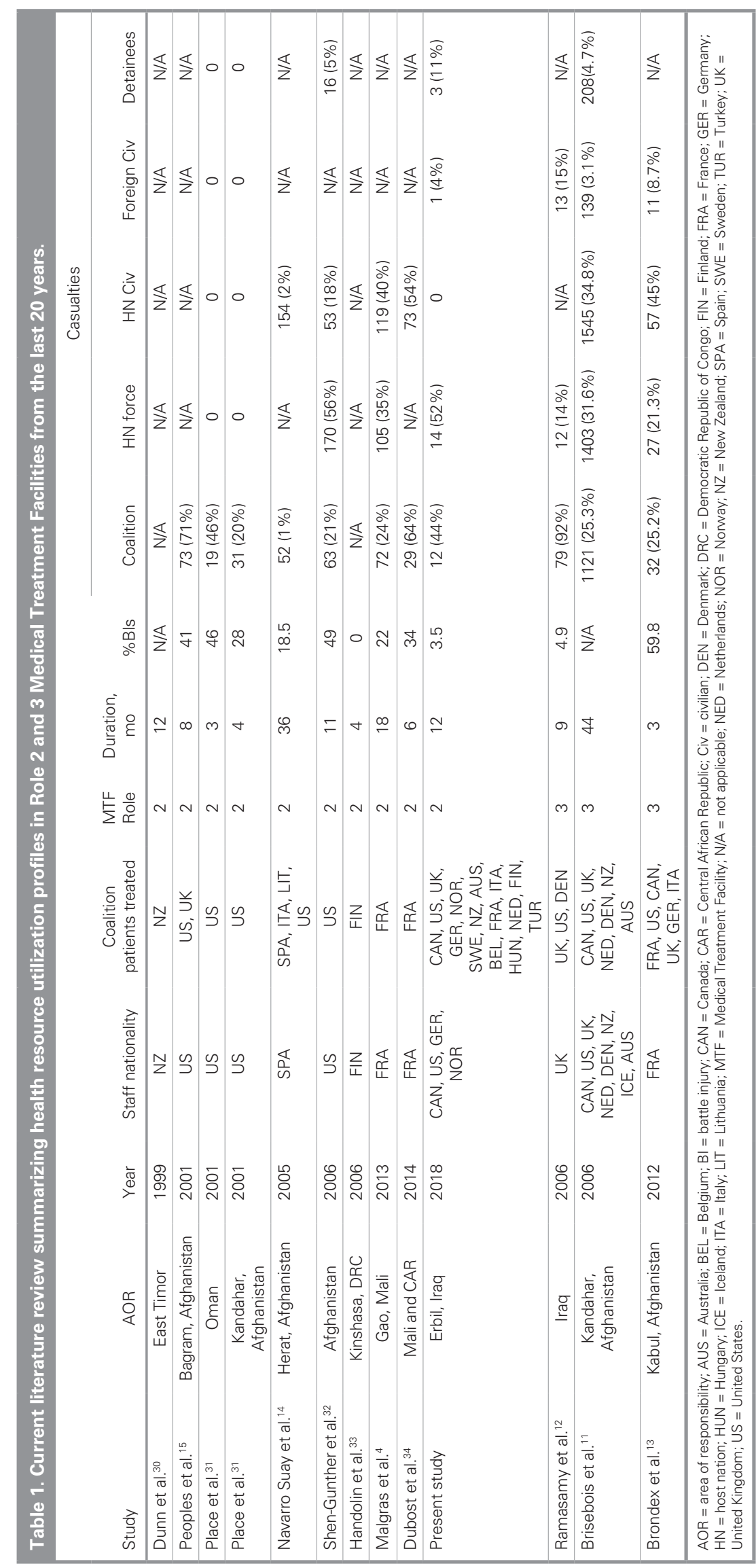


were coalition casualties from 15 countries, most (50\%) were from the United States, $18 \%$ were from Canada and $8 \%$ were from Italy; the other $14 \%$ was evenly distributed among the remaining countries. Of all coalition BIs treated, $75 \%$ were from the United States $(n=9)$ and $25 \%$ were from France $(n=3)$. Regarding the use of ancillary services at the R2MTF, there were 502 radiographs obtained and 482 laboratory investigations performed. During the deployment, the R2MTF used whole blood through activation of the walking blood bank as well as component therapy. When fibrinogen was required as identified through rotational thromboelastometry (ROTEM) analysis, whole blood was used. Of the products given, $50 \%$ were packed red blood cells (pRBCs; $n=64$ units), $45 \%$ were fresh frozen plasma (FFP; $n=57$ units) and $5 \%$ was whole blood from the walking blood bank ( $n=7$ units).

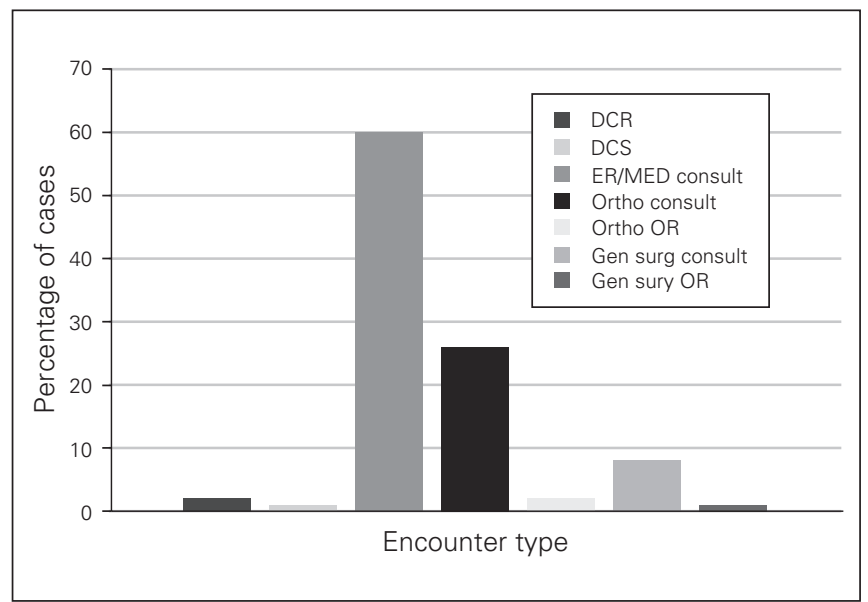

Fig. 1. Coalition patient encounter type (non-dental) by percentage over 12 months. DCR = damage control resuscitation; DCS = damage-control surgery; ER/Med = emergency medicine/internal medicine; General Surgery Consult = general surgery consultation; General Surgery OR = general surgery operation; Ortho Consult $=$ orthopedic consultation; Ortho OR $=$ orthopedic operation.

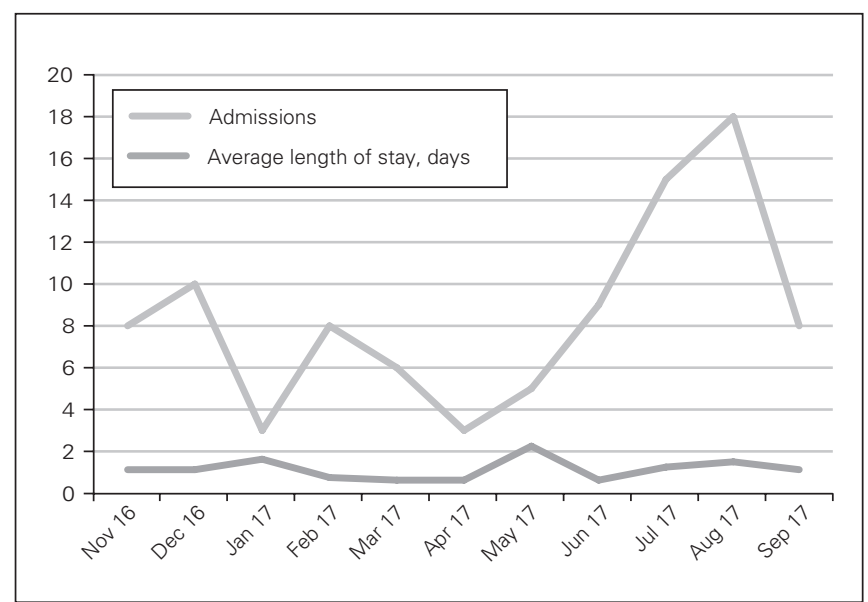

Fig. 3. Number of admissions and average length of stay (days) at the Role 2 Medical Treatment Facility during a 12-month period.

\section{Discussion}

The coalition base in Erbil, Iraq, comprised armed forces representing 15 countries. The Canadian-led R2MTF received patients from all of these nations, each of which had individual medical systems, standards and expectations. Patients were either treated for a return to work within their own forces under the care of their own R1MTF, whose capabilities varied, or prepared for evacuation back to countries with different medical and social support systems. Evacuation was organized by the United States and, therefore, followed CPGs from that country. Canadian physicians would not necessarily be familiar with these CPGs, and occasionally, drugs or equipment specified in the CPGs were not available in Canada. For example, $5 \%$ sulfamylon is specified as an antiseptic to treat burns, but is not available in Canada. ${ }^{17}$ Another example is the use of a catheter system for resuscitative endovascular balloon occlusion of the aorta (REBOA) that is not licensed in Canada. ${ }^{18}$ Medical specialists from 4 different countries made up

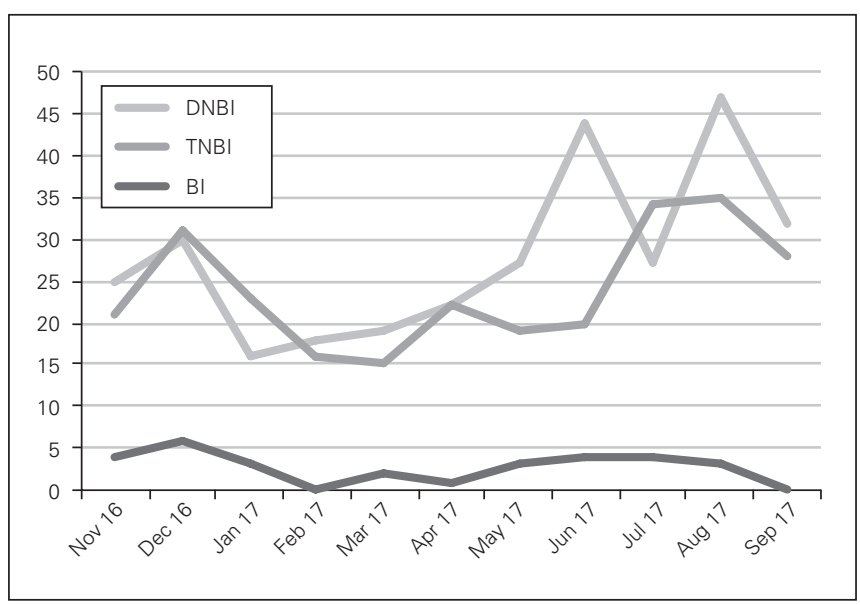

Fig. 2. Number of injuries seen during a 12-month period. $\mathrm{BI}=$ battle injuries; $\mathrm{DNBI}=$ disease non-battle injuries; $\mathrm{TNBI}=$ trauma non-battle injuries.

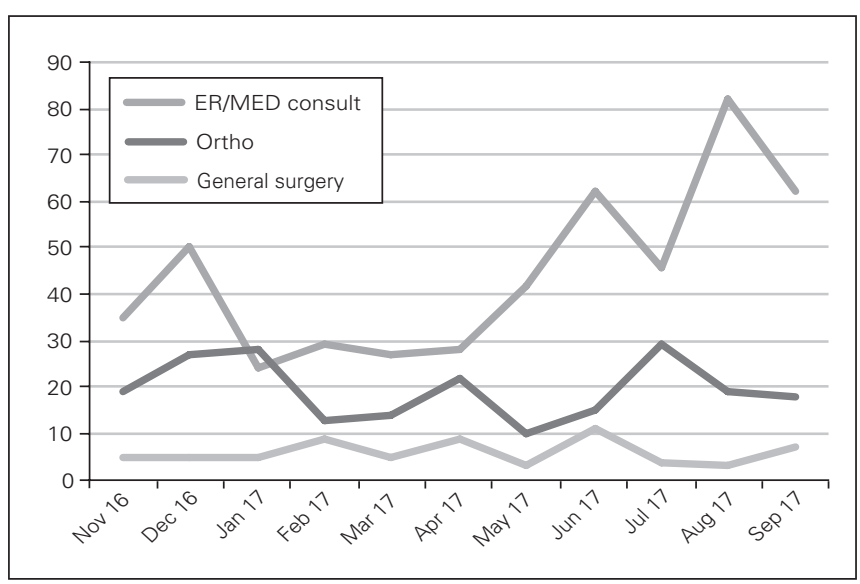

Fig. 4. Number of consultations by specialty at the Role 2 Medical Treatment Facility during a 12 -month period. ER/Med = emergency medicine/internal medicine; Ortho Consult = orthopedic consultation. 
the surgical and resuscitation teams within the R2MTF at various times. Although physical threats and austere environments usually challenge the successful deployment of CAF medical missions, this Canadian R2MTF also found itself within a very complex medical environment owing to international differences combined with varied expectations. These challenges were overcome using a systematic approach from concept to training to operations (Fig. 8).

Since the alliance was founded in 1949, NATO has been striving toward the ability of forces from its $29 \mathrm{mem}-$

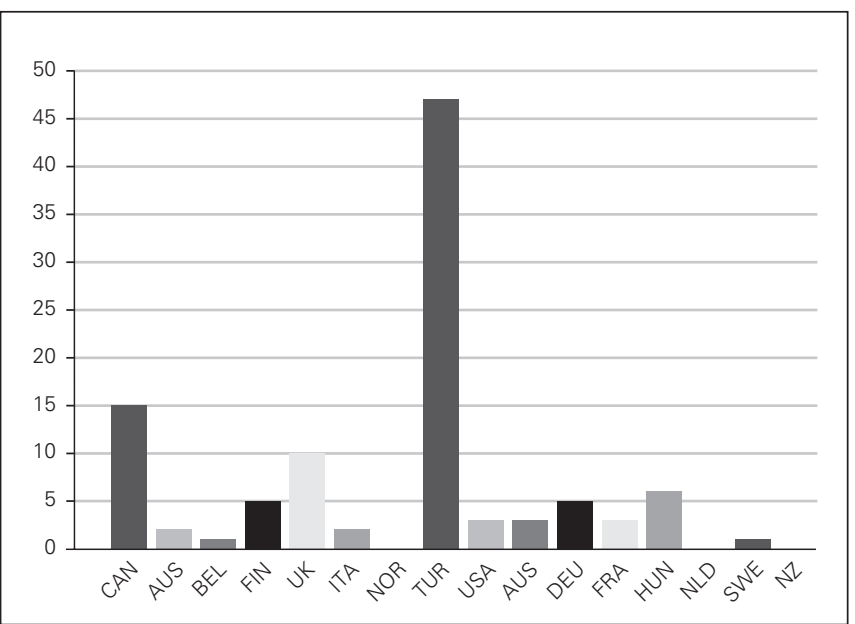

Fig. 5. Percentage of medical patients treated at the Role 2 Medical Treatment Facility by country of origin. AUS = Australia; $\mathrm{BEL}=$ Belgium; CAN = Canada; $\mathrm{DEU}=$ Germany; FIN = Finland; FRA = France; HUN = Hungary; ITA = Italy; NLD = Netherlands; NOR = Norway; NZ = New Zealand; SWE = Sweden; TUR = Turkey; UK = United Kingdom; USA = United States. ber countries to work together. Its interoperability policy entails that allies act together coherently, effectively and efficiently to achieve tactical, operational and strategic objectives. ${ }^{3}$ With respect to combat operations, NATO believes that interoperable solutions can be achieved only through the effective use of standardization, training, exercises, lessons learned, demonstrations, tests and trials; this is also true of medical services, because there are greater disparities among national civilian medical systems than there are in any other fields. These disparities

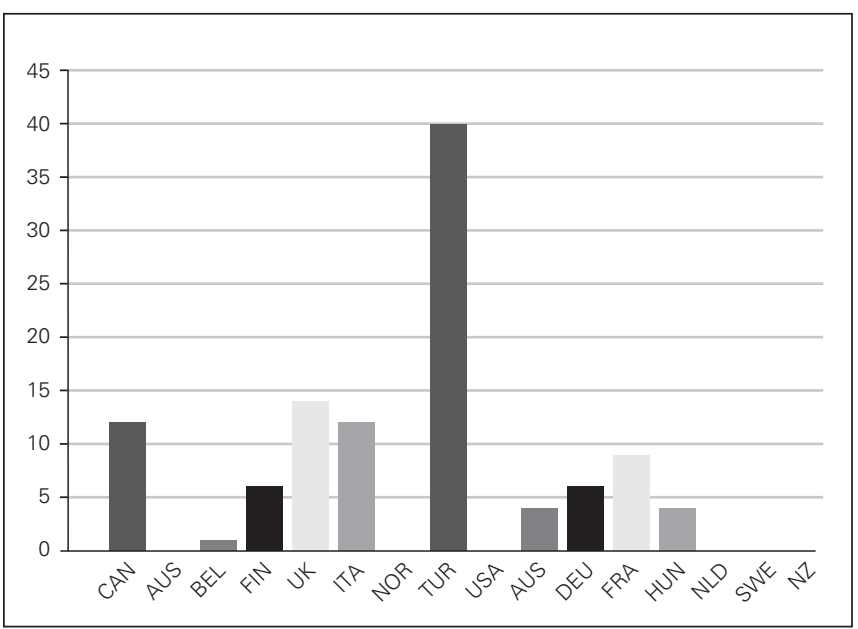

Fig. 6. Percentage of dental patients treated at the Role 2 Medical Treatment Facility by country of origin. AUS = Australia; $\mathrm{BEL}=$ Belgium; $\mathrm{CAN}=$ Canada; $\mathrm{DEU}=$ Germany; FIN = Finland; FRA = France; HUN = Hungary; ITA = Italy; NLD = Netherlands; NOR = Norway; NZ = New Zealand; SWE = Sweden; TUR = Turkey; UK = United Kingdom; USA = United States.

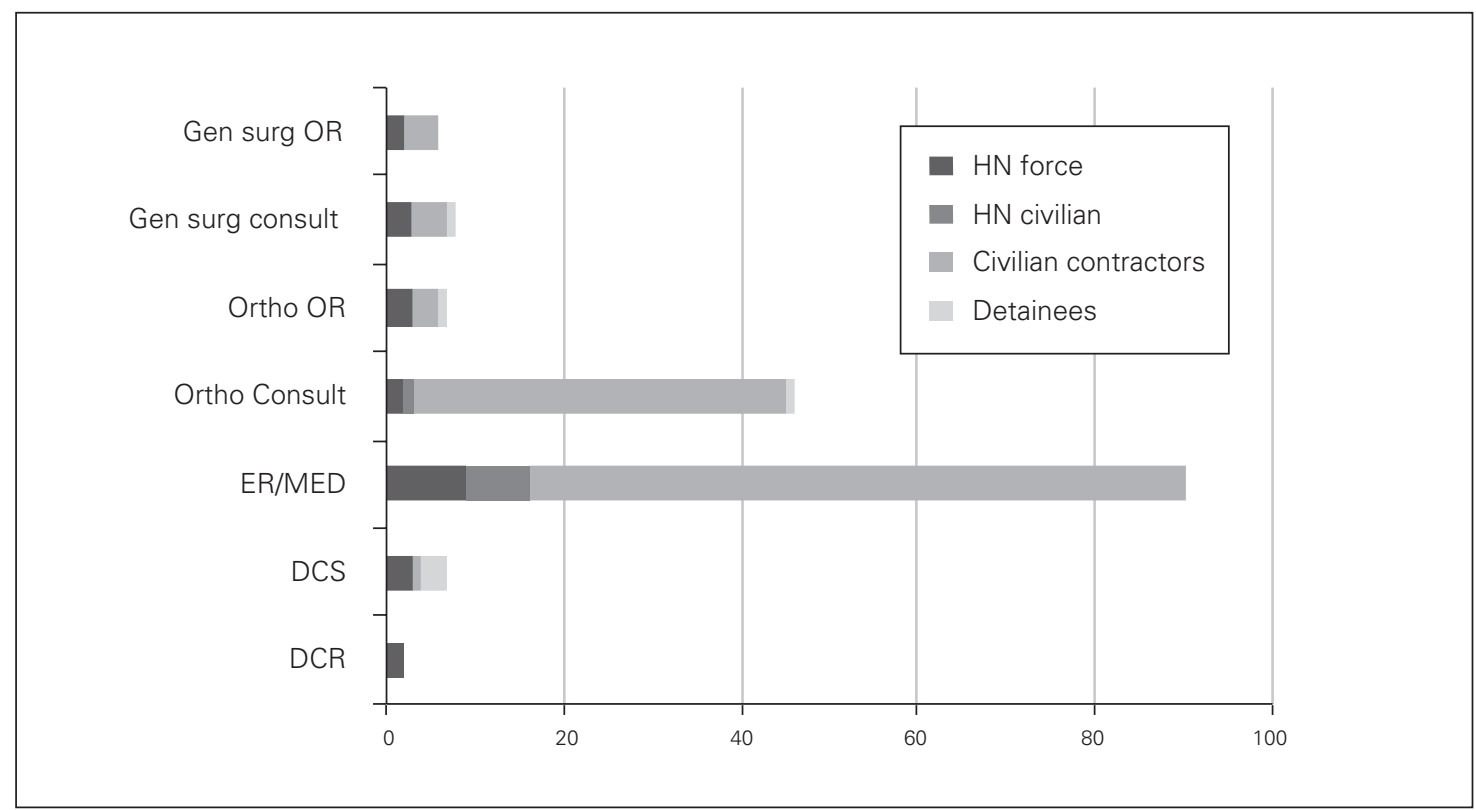

Fig. 7. Number of noncoalition patients treated by type of encounter at the Role 2 Medical Treatment Facility. $\mathrm{DCR}$ = damage-control resuscitation; DCS = damage-control surgery; ER/Med = emergency medicine/internal medicine; General Surgery Consult = general surgery consultation; General Surgery OR = general surgery operation; $\mathrm{HN}=$ host nation; Ortho Consult = orthopedic consultation; Ortho OR = orthopedic operation. 
include different methods and standards of education; different job specifications; different equipment and consumables, including drugs; and nation-specific standard operating protocols.

The Royal Canadian Medical Service (RCMS) has for many years operated overseas in a multinational environment. ${ }^{7,19,20}$ In order to achieve the interoperability required to successfully lead the NATO R2MTF in northern Iraq, a number of strategies were undertaken to overcome disparities in approach by different nations.

First, the US Joint Trauma System (JTS) CPGs for trauma care were the accepted medical standard on which all clinical decisions were based. Canada is a co-author on many of these guidelines, and they have become the standard of care within the RCMS. The Canadian-led R2MTF supplied a complete OR team comprising a general surgeon, orthopedic surgeon, anesthesiologist, perioperative nurse and 2 OR technicians. This team was augmented at different times with an additional OR team - first from Norway and then from Germany. The German OR team comprised a vascular surgeon, a surgical resident in training, a physician anesthesiologist, a nurse anesthetist, an anesthesia technician and an OR technician. Most augmenters spoke English, but not all. Although we took turns being on call for emergency surgery, any cases of predominantly extremity injuries involved the Canadian orthopedic surgeon, and any cases with arterial compromise involved the German vascular surgeon. Regular collective training was performed through lectures, small group-based discussion and simulation. This was done in theatre because there was no multinational predeployment training, and the exact group complement was not known at the time. The degree of interoperability required was possible only because of the excellent communication among team members. The clinical situation dictated the appropriate response; however, it was clear that complementary skill sets from both teams were an asset to clinical and operational effectiveness. ${ }^{21-25}$

Second, the adherence to guidelines is not only predicated on clinical principles of treatment, but also on conforming to specific products and equipment where possible. For example, the current JTS guideline for the use of REBOA as an adjunct to the management of severe hemorrhagic shock calls for the use of an ER REBOA catheter (Prytime Medical, NSN 6515016580745). ${ }^{18}$ Although REBOA was available in the R2MTF, this specific product was not used initially. As other far-forward coalition surgical teams in the area of responsibility were all using the ER REBOA, we felt it necessary to switch to this product so that we were better prepared if a patient arrived with it already in place. Once again, a good working relationship in theatre with other countries' surgical teams was required to establish compatibility of equipment and disposables in evacuating a patient from one facility to another.

Finally, blood product use and the activation of a walking blood bank was another area that exemplified the current disparity among coalition nations and the importance

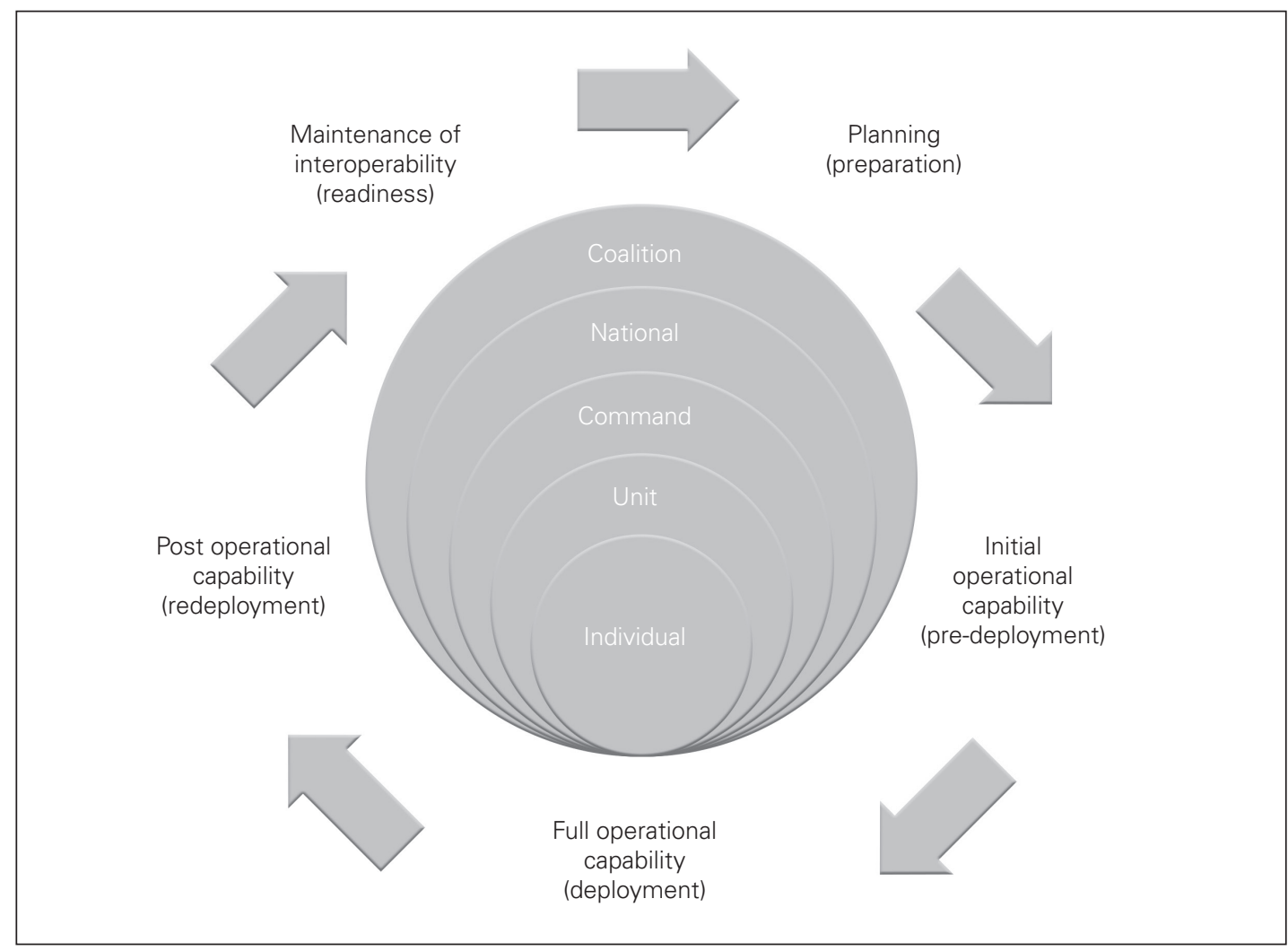

Fig. 8. Medical interoperability readiness cycle. 
of interoperability. ${ }^{26-28}$ The R2MTF had a supply of pRBCs, FFP, fibrinogen and cryoprecipiate. If the need arose for platelets, we activated the walking blood bank to harvest fresh whole blood. Each nation had slightly different modifications of this regimen. The German protocol, for example, was to additionally test any whole blood or pRBCs with bedside ABO-Rh testing using the Eldon card before administration in addition to all other normal checks. The United States, United Kingdom and Canada had similar predeployment screening parameters for establishing a walking blood bank for their own personnel; however, many nations did not have such protocols. It was accepted that in an emergency we would use the Canadian walking blood bank for any coalition members; however, there was no pre-established coalition protocol for this.

With this experience and the likelihood of a requirement for increased interoperability in future NATO medical missions, we propose an MTF readiness framework (Table 2). The clinical basis for the framework is an acceptance of a common CPG standard to which all nations should contribute. This framework involves coalition cooperation in all phases of mission planning and ultimately reflects a cycle of multinational readiness. The NATO Centre of Excellence for Military Medicine (MILMED COE) has been striving to achieve this through collaborations such as Vigorous Warrior excercises as well as participation in a postexercise Final Coordination Conference. Although the training, as it relates to the management of perioperative pathophysiology, is very similar and almost universal in nature, the scope of practice and methodology can vary significantly among different nations. ${ }^{21,22,29}$ In our experience, most European countries employ anesthetic teams consisting of an anesthesia nurse and the physician anesthesiologist. The physician manages the case and performs the technical skills, while the nurse mixes and administers medications, fluids and adjusts the anesthetic as directed. The nurse anesthetist essentially functions as a critical care nurse would in Canada, but within the confines of the OR. They are not trained to administer anesthetics independently, as is the case in the United States, where they may occupy critical roles in resuscitation and evacuation sometimes far forward in the combat environment. In Canada, anesthesiologists typically function independently and may receive assistance from technical staff only when requested. The CAF currently does not provide trained anesthesia nurses or technicians. The scope of practice also differs among international anesthesia providers. In Europe, many, if not most anesthesiologists are dually trained as intensivists. Moreover, given their expertise in nonsurgical aspects of resuscitation, they are often among first responders in prehospital scenarios where they provide early life-saving interventions and escort. In Canada, this role is taken up (albeit to a lesser extent) by trained paramedics and then by emergency physicians on arrival at the hospital. Anesthesiologists and surgeons then provide their unique skill sets to assist the trauma team leader in initial trauma care. This North American model is the typical setup seen in Canadian-led coalition MTFs. In this setting, European anesthesiologists may find themselves relegated to a more supportive role in initial trauma care, whereas in a European-led MTF, a North American anesthesiologist may be expected to take a more active role in the initial assessment and management of trauma patients and potentially postsurgical critical care. Differences in equipment, medications and other tools of the trade are less noticeable and are easily overcome with basic familiarization.

\section{Conclusion}

The experience of the Canadian-led R2MTF in northern Iraq has identified a unique resource utilization profile and highlighted the necessity for adherence to a model of

Table 2. Proposed Multinational Medical Treatment Facility operational readiness framework

\begin{tabular}{|c|c|c|c|c|c|}
\hline & Planning (preparation) & $\begin{array}{l}\text { Initial operational capability } \\
\text { (pre-deployment) }\end{array}$ & $\begin{array}{l}\text { Full operational } \\
\text { capability } \\
\text { (deployment) }\end{array}$ & $\begin{array}{l}\text { Postoperational capability } \\
\text { (redeployment) }\end{array}$ & $\begin{array}{l}\text { Maintenance of interoper- } \\
\text { ability (readiness) }\end{array}$ \\
\hline Individual & $\begin{array}{l}\text { Coalition cultural } \\
\text { awareness }\end{array}$ & $\begin{array}{l}\text { Mission-specific } \\
\text { preparation }\end{array}$ & $\begin{array}{l}\text { Establish integrated } \\
\text { battle rhythm }\end{array}$ & $\begin{array}{l}\text { Members consolidate } \\
\text { equipment and supplies }\end{array}$ & $\begin{array}{l}\text { Physical fitness and } \\
\text { common military skills }\end{array}$ \\
\hline Unit & $\begin{array}{l}\text { Coordinate medical } \mathrm{HQ} \\
\text { communications }\end{array}$ & $\begin{array}{l}\text { High-fidelity simulation } \\
\text { exercises }\end{array}$ & $\begin{array}{l}\text { In-theatre simulation } \\
\text { training }\end{array}$ & $\begin{array}{l}\text { Review mission specific } \\
\text { training }\end{array}$ & $\begin{array}{l}\text { Participate in annual } \\
\text { coalition health care } \\
\text { conference }\end{array}$ \\
\hline Command & $\begin{array}{l}\text { Establish command and } \\
\text { control (C2) framework }\end{array}$ & $\begin{array}{l}\text { Health record and } \\
\text { administration conformity }\end{array}$ & $\begin{array}{l}\text { Facilitate ongoing } \\
\text { educational rounds }\end{array}$ & $\begin{array}{l}\text { Submit AAR with } \\
\text { actionable points }\end{array}$ & $\begin{array}{l}\text { Regular multinational } \\
\text { comined field hospital } \\
\text { exercises }\end{array}$ \\
\hline National & $\begin{array}{c}\text { Respect member } \\
\text { capabilities and preferences }\end{array}$ & $\begin{array}{l}\text { Implement theatre } \\
\text { communication and } \\
\text { information (CIS) training }\end{array}$ & $\begin{array}{l}\text { Acquisition of } \\
\text { aggregated MTF } \\
\text { statistics/data }\end{array}$ & Appropriate rest cycle & $\begin{array}{l}\text { Develop unified medical } \\
\text { standards and CPGs }\end{array}$ \\
\hline Coalition & $\begin{array}{l}\text { Define national responsibili- } \\
\text { ties, tasks, and SOPs }\end{array}$ & $\begin{array}{l}\text { Standardize medical } \\
\text { equipment and mechanism } \\
\text { of resupply }\end{array}$ & $\begin{array}{c}\text { Re-evaluate roles of } \\
\text { care and evacuation } \\
\text { through theatre-wide } \\
\text { VTC }\end{array}$ & Lessons learned & $\begin{array}{l}\text { Adoption of NATO } \\
\text { STANAGs }\end{array}$ \\
\hline
\end{tabular}


medical interoperability readiness for coalition members as the degree of multinational cooperation in health services support of NATO missions is likely to increase.

Affiliations: From the Royal Canadian Medical Service, Canadian Armed Forces (DaCambra, Kao, Berger, McAlister); the Department of Surgery, Sunnybrook Health Sciences Centre, Toronto, Ont. (DaCambra); the Division of Internal Medicine and Critical Care, Western University, London, Ont. (Kao); the Department of Anesthesia, Dalhousie University, Halifax, NS (Berger); and the Division of General Surgery, Western University, London, Ont. (McAlister).

Competing interests: None declared.

Contributors: All authors were attending staff at the R2MTF for periods within the study time interval and helped design the study. M. DaCambra, R. Kao and V. McAlister devised the study, analyzed the data and performed the literature review. M. DaCambra drafted the manuscript. All authors revised and approved the manuscript, had full access to all of the data in the study, and agree to take responsibility for the integrity of the data and the accuracy of the data analysis.

Data sharing: No additional data are available.

Disclaimer: The views expressed in this paper are those of the authors and do not constitute the views or policies of the Canadian Armed Forces.

\section{References}

1. Government of Canada. Operation IMPACT. Ottawa (ON): GOC; 2018. Available: www.forces.gc.ca/en/operations-abroad-current/ op-impact.page (accessed 2018 Aug. 30).

2. Joint Trauma System. Clinical Practice Guidelines. United States Army; 2018. Available: http://jts.amedd.army.mil/index.cfm/PI_ CPGs/cpgs (accessed 2018 Aug. 30).

3. North Atlantic Treaty Organization. Interoperability: Connecting NATO Forces. NATO; 2017. Available: www.nato.int/cps/em/ natohq/topics_84112.htm (accessed 2018 Aug. 30).

4. Malgras B, Barbier O, Petit L, et al. Surgical challenges in a new theater of modern warfare: the French role 2 in Gao, Mali. Injury 2016;47:99-103.

5. Unlu A, Cetinkaya RA, Ege T, et al. Role 2 military hospitals: results of a new trauma care concept on 170 casualties. Eur 7 Trauma Emerg Surg 2015;41:149-55.

6. Jacobs N, Taylor DM, Parker PJ. Changes in surgical workload at the JF Med Gp Role 3 Hospital, Camp Bastion, Afghanistan, November 2008-November 2010. Injury 2012;43:1037-40.

7. Brisebois RJ, Tien HC. Surgical experience at the Canadian-led Role 3 Multinational Medical Unit in Kandahar, Afghanistan. 7 Trauma Inj Infect Crit Care 2011;71(Suppl 1):S397-400.

8. Tubb CC, Oh JS, Do NV, et al. Trauma care at a multinational United Kingdom-led Role 3 combat hospital: resuscitation outcomes from a multidisciplinary approach. Mil Med 2017;179:1258-62.

9. Shah K, Pirie S, Compton L, et al. Utilization profile of the trauma intensive care unit at the Role 3 Multinational Medical Unit at Kandahar Airfield between May 1 and Oct. 15, 2009. Can 7 Surg 2011;54:S130-4.

10. Mann-Salinas EA, Le TD, Shackelford SA, et al. Evaluation of role 2 (R2) medical resources in the Afghanistan combat theater: initial review of the joint trauma system R2 registry. 7 Trauma Acute Care Surg 2016 Nov;81:S121-7.

11. Brisebois R. The Role 3 Multinational Medical Unit at Kandahar Airfield 2005-2010. Can 7 Surg 2011;54:S124-9.

12. Ramasamy A, Harrisson S, Lasrado I, et al. A review of casualties during the Iraqi insurgency 2006-a British field hospital experience. Injury 2009;40:493-7.

13. Brondex A, Viant E, Trendel D, et al. Medical activity in the conventional hospitalization unit in Kabul NATO Role 3 Hospital: a 3-month-long experience. Mil Med 2014;179:197-202.
14. Navarro Suay R, Abadia de Barbara AH, Gutierrez Ortega C, et al. Gunshot and improvised explosive casualties: a report from the Spanish Role 2 medical facility in Herat, Afghanistan. Mil Med 2012;177: 326-32.

15. Peoples GE, Gerlinger T, Craig R, et al. Combat casualties in Afghanistan cared for by a single forward surgical team during the initial phases of Operation Enduring Freedom. Mil Med 2005;170:462-8.

16. Belmont PJ, Goodman GP, Waterman B, et al. Disease and nonbattle injuries sustained by a U.S. Army brigade combat team during Operation Iraqi Freedom. Mil Med 2010;175:469-76.

17. Driscoll IR, Mann-Salinas EA, Boyer NL, et al. Burn Care (CPG ID: 12). Joint Trauma System Clinical Practice Guideline. Available: http:// jts.amedd.army.mil/assets/docs/cpgs/JTS_Clinical_Practice_Guidelines _(CPGs)/Burn_Care_11_May_2016_ID12.pdf (accessed 30 Aug. 2018).

18. Pasley S, Cannon J, Glaser J et al. Resuscitative Endovascular Balloon Occlusion of the Aorta (REBOA) for Hemorrhagic Shock (CPG ID: 38) Available: http://jts.amedd.army.mil/assets/docs/cpgs/JTS_Clinical_ Practice_Guidelines_(CPGs)/REBOA_for_Hemorrhagic_Shock_06_Jul _2017_ID38.pdf (accessed 30 Aug. 2018).

19. Tien HC, Farrell R, Macdonald J. Preparing Canadian military surgeons for Afghanistan. CMA7 2006;175:1365.

20. Pannell D, Brisebois R, Talbot M, et al. Causes of death in Canadian Forces members deployed to Afghanistan and implications on tactical combat casualty care provision. 7 Trauma Inj Infect Crit Care 2011;71:S401-7.

21. Kellicut DC, Kuncir EJ, Williamson HM, et al. Surgical team assessment training: improving surgical teams during deployment. Am 7 Surg 2014;208:275-83.

22. Pasquier P, Dubost C, Boutonnet M, et al. Predeployment training for forward medicalisation in a combat zone: the specific policy of the French Military Health Service. Injury 2014;45:1307-11.

23. Pollak AN, Ficke CJR, Extremity War Injuries IV Session Moderators. Extremity war injuries: collaborative efforts in research, host nation care, and disaster preparedness. 7 Am Acad Orthop Surg 2010;18:3-9.

24. Ramasamy A, Hinsley DE, Edwards DS, et al. Skill sets and competencies for the modern military surgeon: lessons from UK military operations in Southern Afghanistan. Injury 2010;41:453-9.

25. Beckett A, Pelletier P, Mamczak C, et al. Multidisciplinary trauma team care in Kandahar, Afghanistan: current injury patterns and care practices. Injury 2012;43:2072-7.

26. Powell-Dunford N, Quesada JF, Gross KR, et al. Army air ambulance blood product program in the combat zone and challenges to best practices. Aerosp Med Hum Perform. 2016;87:728-34.

27. Beckett A, Callum J, da Luz LT, et al. Fresh whole blood transfusion capability for Special Operations Forces. Can F Surg 2015;58:S153-6.

28. Sicard B, Marouzé F, Roche C, et al. Bleeding management in remote environment: the use of fresh whole blood transfusion and lyophilised plasma. Int Marit Health 2016;67:79-82.

29. Tai N, Hill P, Kay A, et al. Forward trauma surgery in Afghanistan: lessons learnt on the modern asymmetric battlefield. 7 R Army Med Corps 2008;154:14-8.

30. Dunn AC. East Timor: the work of the New Zealand Forward Surgical Team from 1999 to 2000. Mil Med 2002;167:810-1.

31. Place RJ, Rush RM Jr, Arrington ED. Forward surgical team (FST) workload in a special operations environment: the 250th FST in Operation ENDURING FREEDOM. Curr Surg 2003;60:418-22.

32. Shen-Gunther J, Ellison R, Kuhens C, et al. Operation Enduring Freedom: trends in combat casualty care by forward surgical teams deployed to Afghanistan. Mil Med 2011;176:67-78.

33. Handolin L, Elomaa T. The Finnish forward surgical team experience during EUFOR Operation RD Congo in 2006. Eur 7 Trauma Emerg Surg 2007; 33: 245-50.

34. Dubost C, Goudard Y, Soucanye de Landevoisin E, et al. Combat casualties from two current conflicts with the seventh French forward surgical team in Mali and Central African Republic in 2014. $7 \mathrm{R}$ Army Med Corps 2016;162:450-455. 